SHS Web of Conferences 12, 01099 (2014)

DOI: $10.1051 /$ shsconf/ 20141201099

(C) Owned by the authors, published by EDP Sciences, 2014

\title{
Long Journey Travel to Tourist Destination: A Review Paper
}

\author{
Norkamaliah Shahrin ${ }^{1}$, Ahmad Puad Mat Som², Jamil Jusoh ${ }^{3}$ \\ ${ }^{1,2,3}$ School of Housing, Building and Planning, Universiti Sains Malaysia, 11800, Penang, Malaysia
}

\begin{abstract}
Tourists are now more open in selecting tourist destination. The number of holiday trips were growing rapidly. There were various promotions available to attract tourists to travel either within or outside the country. Travel distance is not an obstacle for tourists to travel, regardless of local and foreign destination. This study will be conducted to identify the motivation of long journey travel that involves push and pull factors. The long journey involves distance, cost and the type of transportation used to get to the destination. For this purpose a comprehensive review and discussion on previous sources which involved a variety of secondary data sources will be used to meet every need of the study objectives. The finding showed that the travel distance was dependent on the motivation for tourists to travel and the type of transport they want to use. Mode of transport used has advantages and disadvantages for long journey travel depending on traveller choice.
\end{abstract}

\section{Introduction}

Tourists demanded for more interesting places to visit, with more memorable experience to share with family and friends. Somehow, most tourists were offered with more destinations and tour package options that were cheap and affordable. Travel is a component of the tourism product that gives a satisfaction, while travel distance has become a choice [1]. Travel distance can be a positive and negative influence $[2,3]$ that depends on the characteristics of travel and the individual preference. The distance between individual's hometown with the destination is particularly important in establishing the criteria selection of tourist travel dimension [4]. It does not matter if the journey is time-consuming, since according to [5] long journey tend to be more organised and tourist usually spends more time gathering information about the trip [6]. According to [7] longer distance travel usually requires much time commitment. Wider and more various options of transport mode for the destination of choice are available that gives comfort and satisfaction, with more reasonable prices depending on individual preferences.

\section{Concept of motivation in travel}

Motivation affects the overall individual action [8]. If there is no motivation to travel, the tourism industry would not exist [9]. [10-11] stated that motivation could be critical in understanding the different tourist's desire for tourism markets and market segmentation. According to [12] it is difficult to list down reasons on travel and how a tourist achieves the desired satisfaction. Motivation is defined by [13] as the need or desire and stimulus to achieve the goal behaviour. [14] stated that, tourists behave as they do because of motivation. Escape from the actual routine, relaxation, prestige, 
nostalgia, improved relationships, social interaction, adventure, health, personal development, something different, education, seclusion and romance are common reasons of tourist motivation [14]. The basic motivation theory describes a dynamic process of internal psychological factors (needs, desires and goals) that will produce a level of discomfort, tension and this will meet the requirements.

Motivation trip according to [15] is related to individual's socio-economic or/and psychological conditions or/and background characteristics. Psychological conditions are interpreted, especially the hidden features that are held by a group of users compared that of the other users. [15] noted that the psychological segmentation is the first step in the process of identifying member groups. When these psychological characteristics have been identified, the analysis will reveal the specific characteristics found in each group that have in common.

\section{Factors that contribute to motivaton of travel}

Motivation gives impact on the satisfaction formation [16]. Motivation is an important factor in influencing individual decisions. People are motivated to travel when they become conscious of the need and perceive that certain destination may not have the ability to serve those needs $[17,18]$. Attention is particularly relevant in stimulating the desire to meet the satisfaction level. With regard to a certain stimulus it will not achieve the desired satisfaction. However, it also depends on the individuals, since every tourist had different expectation. According to [19], motivation arises out of the feel, desire or need of the individual. He claimed that motivation is expressed in a distinct two forms, known as general motivation (getting away from routine) and specific motivation holiday taking in the Swiss Alps. Many researchers argue that tourists travel due to push and pull factors by a destination [20]. The pull factors are related to internal factors that motivate individuals to travel, while the push factors are related to the external factors that determine their travel on where, when and how [21]. [22] state that pull and push factors are acting separately and tourists travel due to the variable interests motivation in making travel decisions. According [23] most of the push factors which are origin-related are intangible or intrinsic of the individual travellers, while the pull factor on the contrary, are those that are emerged as a result of the attractiveness of a destination as it is perceived by the travellers.

\section{Long journey travel: How and why?}

Transport plays an important role in tourists and provide a very meaningful travel experience for them. [24] state that the quality of the transportation experience is a key criterion in choosing destination. For long journey travel, tourist usually uses public transport such as planes, high speed trains and conventional, bus or private vehicles such as car. [25] noted that the use of public transport is convenient and provides satisfaction to the tourists. According to the World Tourism Organization (UNTWO) the concept of long journey travel based on the Dateline European project comprises a minimum $100 \mathrm{~km}$ journey [26]. Travel distance may be divided into two routes which is in the country or traveling abroad. [27] state that long journey travel might have concerns about visas, travel safety and impressions held by the unfamiliar long journey destination. Most of the long journey travellers are also not confident enough to travel independently due to their lack of travel experience or information about the destination [28].

\subsection{Motivation for choosing a destination}

It is difficult to determine the factors that influence tourist motivation in choosing a travel destination, and it depends on tourist behavior because according [9], certain force drive individual to act. Past researchers also state that motivation to travel is considered as a key factor in explaining tourist behaviour. Different type of tourist has different type of behaviour. [2] the influence of distance on 
destination choice might be depending on the tourist's motivations. He examined the motivation such as search for relaxion, good climate of destination, curiosity and visiting friends and relatives.

\subsection{Distance}

Distance according to [3] can be considered as travel time or having enough time in the destination. According to [26] the influence of distance is important. Cultural distance according to [29] are the consideration that should be noted. They stated that non-culturally distance traveller who is unable to cope with huge cultural differences will restrict their destination choice of culturally similar destination with their home region and tends to travel for recreation, refreshment, hedonism and replenishment. For example, travelling from Malaysia to Thailand might be culturally similar to each other. On the other hand, traveller with interest to different culture will tend to travel to further destination. This type of travellers will see travel activity asas an opportunity for self development and as a change to learn [29]. For example traveller from Europe travelling to Asia (between east and west) will travel to a place that is so significantly different, culturally.

\subsection{Economic of Travel}

According to [26] most authors agree that travel time and cost are important variables. [27] stated that long journey traveller are less sensitive to price and tourist are willing to pay more compare to short traveller [6]. According to [2] distances have different influences on the individual, depending on their income level. High-income individuals can gain access to long journey destinations, which is more expensive according to the distance. Therefore, the negative impact of distance to high-income individuals is low. [26] state that price sensitivity seems to depend on the availability of substitute destination. However, [27] states that tourist is very aware of the cost of transportation since the decision about transportation is related to decision about destination.

\section{Transport Selections}

Distant sensitivity depends on transportation mode in which individual traveler [2]. He also states that the desire to travel is based on transport mode selected for the trip such as physical, temporal, and financial effort changes according to the mode used. According to [30], the choice of transport are depend upon a variety of factors such as safety, time/speed, comfort, cost convenience, reliability, flexibility and availability.

\subsection{Airplane}

Air travel is always in demand. It is commonly used for tourism and business purposes [31]. According to [31], the use of airplane depends on the strategic planning and development, from the quantitative understanding. Long journey travel by airplane involves more than 5 hours or travel distance of more than 3,000 miles travel destination [6]. Travelling by plane is a simple, flexible, fast and efficient, especially for long distance travel. Now, there are various promotions especially from the low cost carriers that attract tourist to travel to more distant destinations. However, the use of airplane does not give satisfaction compared to the use of land transport due to the purpose of the travellers themselves in to the destination of choice.

\subsection{Train (high speed and conventional)}

Travelling by train helps the travellers to get to isolated area that are difficult to be connected with the use of other transport modes. Trains provide a variety of variant image or panorama along the way, especially in rural areas. However, the use of trains (conventional) sometimes takes a long time, 
causing traveler has no activities to do [32] along the way compared to the use of high-speed trains. In addition, the transit station that only stops to pick up and drop off passengers, making train as a choice for travel less compared to other modes of transport. The highest use of trains is between 600 to $900 \mathrm{~km}$ and it is lowest at a distance of $100-200 \mathrm{~km}$ and between $1100-1400 \mathrm{~km}$. However, Goeverden [24] also states that train travel is only competitive on shorter distance ranging less than $1,500 \mathrm{~km}$ share of tourists in this travel range are low. Crossing national borders proves to substantially reduce train use [24]. Based on European survey the international trip by trains is only about $30 \%$ that of choosing the train for the similar domestic trip. Belgian and Swiss residents are the highest train user compared to Portuguese, Spanish and Irish. While, single travellers are the highest train users in Australia [24]. Canadian Rocky Mountaineer, Trans-Siberian Rail, Silk Railways, Amtrak Rail, Rail Queensland and Thai Railways are some example of the long distance travel by train. According to [33], Trans Siberian Rail is the longest route with a length of $9297 \mathrm{~km}$ links Russia to Mongolia and China.

\subsection{Car / Bus}

Using a car to travel will give satisfaction and advantages. Trips that are not bound can stop anytime and gives a panoramic views along the way. In addition, most users prefer to use private vehicles, especially in Malaysia. For example, driving long journey exceeding $100 \mathrm{~km}$ is not a major obstacle, with rest and treat $(\mathrm{RnR})$ areas are available along the highway. Road network system that makes the use of private vehicles is a preferred choice. Similarly, wider range of tour bus packages is becoming a tourist's preference method to travel. Long journey travel by bus usually offers a very affordable package. However, long journey travel by public transport services is not a common practice, especially in the Asian countries (except developed countries such as Japan and Korea, which have good transport services particularly in terms of timeliness). In Europe and Australia for example, travellers choose to rent a caravan for trip to visit more places with more enjoyment. Usually, tourists rent caravan while traveling with family and friends, since it is too expensive for all family members to pay the airplane ticket [2].

According [26] there is a clear competition between trains and cars, while competition between trains and planes only for high-speed trains. According to [2] train is related to long distance and it's more comfortable than a car, but not as expensive. Maason and Petiot (2009) state that railway can significantly ease access and is a vital tool for tourism destination development.The use of airplanes and high-speed trains (more concentrated in Europe) is easy especially for long journey travel. For examples, tourists who travel around Europe or European travellers who travel to Asia. [2] stated that travel time can be a factor in productivity. For example, a tourist traveling long distance will option to travel by car than a short trip on a plane to a remote destination, mainly because for sight-seeing. However, on the contrary, for [34], the rail system is beneficial compared to road travel, based on time, safety and comfort purposes. They also express that rail travel has the potential to enhance the overall tourist experience. The effect of distance can meet the level of people's satisfaction with the increased utility of the destination [35].

\section{Discussion and Conclusions}

The transport is very important in providing customer satisfaction and travel experience to tourists. Satisfaction will provide quality travel experience to travellers, as every tourist has different satisfaction and experiences. Competition between transport operators also has an impact in selecting the mode of transportation for tourists. Tourists begin to choose air transport for long journey travel $[2,36]$ since there are more promotions. Based on the discussions, distance and cost factors are very important in choosing destination for long journey travel. However, analysis of the effect of distance to the destination of choice for tourism is still lack in the research areas.

Long journey travel often tends to be carefully planned, especially for first time traveler. Normally, long journey tourists consists of a group or family travellers. Long journey travel behavior 
is also dependent on the socio-economic traveler to travel. Push and pull factors also influence the motivation of long journey travel. Factors such as distance and cost affect long journey travel, because the farther the distance traveled will increase cost of travel destination. Public or private transport are a choice of travellers, whether traveling far made inside or outside the country. Travel distance does not have a specific limit. It depends on the tourists in choosing destinations with their choice of transport mode. There are a variety of transportation options to choose from tourists in convenience and comfort of tourists on the way to the destination.

\section{Acknowledgement}

This project is partially funded by a research grant from the Universiti Sains Malaysia, Research University Grant No. 1001/PTS/8660013.

\section{References}

1. M. J. Baxter. The Interpretation of the Distance and Attractiveness Components Models of Recreational Trips. Geographical Analysis, 11 , 3,311-15 (1980)

2. J.L. Nicolau. Characterizing Tourist Sensitivity to Distance. Journal of Travel Research,. 47, 43-52 (2008)

3. T. Harrison-Hill. Implication of Long Houl Travel on the Marketing of International Tourism, Unpublished PhD Thesis, Griffith University, Queensland, Australia (2000)

4. J.L. Nicolau \& F.J. Mas. The Influence of Distance and Price on the Choice of Tourist Destination: The Moderating Role of Motivations. Tourism Management 27, 982-996 (2006)

5. M. Wardman. Public Transport Value of Time. Transport Policy, 11, 363-377 (2004)

6. P. Boerjan. Do We Need A Distinction Between Short and Long Holidays? The Tourist Review, 33, 11-17 (1995)

7. B. McKercher. The implication effect of distance on tourist of distance on tourist behavior: A comparison of short and long haul pleasure tourist to Hong Kong. Journal of Travel and Tourism Marketing, 25,3-4 (2008)

8. J. Adair. Understanding Motivation. Guidford: Surrey Talbot Adair Press (1990)

9. H. Kassean \& R. Gassita. Exploring Tourists Push and Pull Motivations to Visit Mauritius as a Tourist Destination. African Journal of Hospitality, Tourism and Leisure 2 , 3(2013)

10. J.L. Crompton. Motivations for Pleasure Vacation. Annals of Tourism Research, 6, 4, 408-424 (1979)

11. Y.S. Lee. Gazing at Kum Kang Mountain: The Emergence of Commercial Tourism in South Korea. $29^{\text {th }}$ International Geographical Congress: $14^{\text {th }}-18^{\text {th }}$, Seoul, Korea (2000)

12. Y. Yoon, M.S. Uysal. An examination of the effects of motivation and satisfaction on destination loyalty: a structural model. Tourism Management, 26 , 1, 45-56 (2005)

13. D.G. Myers. Exploring Psychology. Holland: Worth Publishers (2004)

14. C. Hsu, L. Killion, G. Brown, M.J. Gross \& S. Huang. Tourism Marketing: An Asia-Pasific Perspective. John Wiley \& Sons Australia. Ltd (2008)

15. W.C. Gartner. Tourism Development: Principle, Process, and Policy. International Thompson Publishing Company (1996)

16. J. Gnoth. Tourism Motivation and Expectation Formation. Annals of Tourism Research, 24, No. , 2, 283-304 (1997)

17. B. Lubbe. Primary Image as a Dimension of Destination Image: An Empirical Assessment. Journal of Travel and Tourism Marketing, 7 , 4, 21-43 (1998)

18. J.K.L. Chan \& T. Baum. Ecotourist's Perception of Ecotourism Experience in Lower Kinabatangan, Sabah, Malaysia. Journal of Sustainable Tourism, 15, 5, 575-590 (2007)

19. J.C. Holloway. The Business of Tourism. Prentice Hall, Six Edition (2002)

20. A. Correia, M. Kozak \& J. Freeadeira. From Motivation to Tourist Satisfaction. International Journal of Cultural, Tourism and Hospitality Research. 7 No 4 2013, 411-424 (2013) 
21. S.S. Jang \& L.A. Cai. Travel Motivations and Destination Choice: A Study of British Outbound Market. Journal of Travel and Tourism Marketing, 13 , 3, 111-133 (2002)

22. M. Uysal \& L. Hagan. An Exploratory Study of Factors of Japanese Tourism Demand for the UK. International Journal of Contemporary Hospitality Management. 13, 2, 70-78 (1993)

23. A.M. Bashar. Motivation Factors Influencing Foreign Tourists To Jordan: Case Studies of Amman and Petra. Unpublished PhD Thesis. Universiti Sains Malaysia (2011)

24. B. Lumd \& S. Davidson. Tourism and Transport in Otario, Canada in L. Harrison and W. Husbands (eds). Practising Responsible Tourism: International Case Studies in Tourism Planning, Policy and Development, Chichester: Wiley, 261-276 (1996)

25. K. Thompson \& P. Schofield. An investigation of the relationship between public transport performance and destination satisfaction. Journal of Transport Geography, 15, 136-144 (2007)

26. C.D.V. Goeverden. Explanation Factors for Train Use in European Long-Distance Travel. Tourism and Hospitality Planning \& Development, 6:1, 21-37, DOI: 10.1080/14790530902847038

27. Crouch, G. I. (1994). Demand Elasticities for Short -Haul Versus Long Haul Tourism, Journal of Travel Research, 34, 2-7 (2009)

28. A. Lo \& T. Lam. Long-Haul and Short-Haul Outbound All-Inclusive Packages Tours. Asia Pasific Journal of Tourism Research, 9, 2, 161-176 (2004)

29. B. McKercher \& H. du Cros. Testing the cultural tourism typology. International Journal of Tourism Research, 5, 1, 45-58 (2003)

30. R. Sharpley. Travel and tourism. Sage Publication London: Thousand Oaks: New Delhi (2006)

31. J. Cazanova, R.W. Ward \& S. Holland. Habit Persistence in Air Passengers Traffic Destined for Florida. Journal of Travel Research, 0047287513513173 (2013)

32. M.S. Ming. The Qinghai-Tibet Railways and Tibet Tourism: Travelers Perspectives. Master Thesis. University of Waterloo, Waterloo, Otario, Canada (2007)

33. S. Otsuka. Central Asia's Rail Network and the Eurasian Land Bridge. Japan Railways and Transport Review 28 (2001)

34. C. Becker \& B.P. George. Rapid Rail Transit and Tourism Development in the United State. Tourism Geographies. Vol. 13, No. 3, 381-397 (2011)

35. P.L. Mokhtarian \& I. Solomon. How Derived Is the Demand for Travel? Some Conceptual and Measurement Consideration, Working Papers Series, Institute of Transport Studies, University of California, Davis (2001)

36. B. Prideaux. Track to Tourism: Queensland Rail Joins the Tourist Industry. International Journal of Tourism Research, 1, 73-86 (1999) 